www.mdpi.com/journal/marinedrugs

Article

\title{
Tanjungides A and B: New Antitumoral Bromoindole Derived Compounds from Diazona ef formosa. Isolation and Total Synthesis
}

\author{
Carmen Murcia ${ }^{1}$, Laura Coello ${ }^{1}$, Rogelio Fernández ${ }^{1}$, María Jesús Martín ${ }^{1}$, Fernando Reyes ${ }^{2}$, \\ Andrés Francesch ${ }^{1}$, Simon Munt ${ }^{1}$ and Carmen Cuevas ${ }^{1}$ * \\ 1 Medicinal Chemistry Department, PharmaMar S.A., Avda. de los Reyes 1, Pol. In. La Mina, \\ Colmenar Viejo, Madrid 28770, Spain; E-Mails: cmurcia@pharmamar.com (C.M.); \\ 1coello@pharmamar.com (L.C.); rfernandez@pharmamar.com (R.F.); \\ mjmartin@pharmamar.com (M.J.M.); afrancesch@pharmamar.com (A.F.); \\ smunt@pharmamar.com (S.M.) \\ 2 Fundación MEDINA, Avda. del Conocimiento 3, Parque Tecnológico de Ciencias de la Salud, \\ Granada 18016, Spain; E-Mail: fernando.reyes@medinaandalucia.es \\ * Author to whom correspondence should be addressed; E-Mail: ccuevas@pharmamar.com; \\ Tel.: +34-91-846-6029; Fax: +34-91-846-6001.
}

Received: 2 December 2013; in revised form: 16 December 2013 / Accepted: 24 January 2014 / Published: 21 February 2014

\begin{abstract}
Tanjungides A (1) ( $Z$ isomer) and B (2) ( $E$ isomer), two novel dibrominated indole enamides, have been isolated from the tunicate Diazona cf formosa. Their structures were determined by spectroscopic methods including HRMS, and extensive 1D and 2D NMR. The stereochemistry of the cyclised cystine present in both compounds was determined by Marfey's analysis after chemical degradation and hydrolysis. We also report the first total synthesis of these compounds using methyl $1 H$-indole-3-carboxylate as starting material and a linear sequence of 11 chemical steps. Tanjungides A and B exhibit significant cytotoxicity against human tumor cell lines.
\end{abstract}

Keywords: bromoindole; tunicate; Diazona cf formosa; cytotoxicity; isolation; structure elucidation; total synthesis 


\section{Introduction}

Ascidians [1] are a rich source of bromoindole derived metabolites such as eudistomin [2], didemnimide [3], meridianin [4], coscinamide [5], rhopaladin [6], kottamide [7,8] and aplicyanin [9]. Most of these compounds exhibit antiviral, antibacterial and anti-inflammatory activity as well as cytotoxicity against tumor cell lines. The diazonamides isolated from Diazona angulata (originally misidentified as Diazona chinensis) [10] and Diazona sp. [11] provide a further example of secondary metabolites from ascidians. Strong cytotoxic activity has been reported for these compounds with $\mathrm{IC}_{50}$ values in the nanomolar range. As part of work to study marine organisms from Indonesia, we have examined the constituents of the tunicate Diazona cf formosa collected off the coast of Tanjung Liarua and Toro Doro (Timor Island). In this paper we report the isolation, structure elucidation and synthesis of two new indole alkaloids Tanjungides A and B (1 and 2). Tanjungides are novel alkaloids containing a dibromoindole joined to a disulfide dipeptide by an enamide bond.

\section{Results and Discussion}

\subsection{Isolation and Structure Elucidation}

Cytotoxicity bioassay-guided fractionation of an organic extract of the organism, including VLC RP-18 chromatography followed by reverse-phase preparative HPLC of selected active fractions, led to the isolation of Tanjungides A and B.

Compound $\mathbf{1}$ was isolated as an optically active pale yellow amorphous solid with a pseudomolecular ion in the (+)-HRESIMS at $\mathrm{m} / \mathrm{z} 518.9142$ and an isotopic cluster consistent with the presence of two bromine atoms. The presence of 16 signals in the ${ }^{13} \mathrm{C}$ NMR spectrum (Table 1) was also in agreement with the molecular formula $\mathrm{C}_{16} \mathrm{H}_{16}{ }^{79} \mathrm{Br}_{2} \mathrm{~N}_{4} \mathrm{O}_{2} \mathrm{~S}_{2}\left(\mathrm{~m} / z\right.$ 518.9142 $[\mathrm{M}+\mathrm{H}]^{+}$, calcd. for $\mathrm{C}_{16} \mathrm{H}_{17}{ }^{79} \mathrm{Br}_{2} \mathrm{~N}_{4} \mathrm{O}_{2} \mathrm{~S}_{2}$, 518.9154). The presence of a 3,5,6-trisubstituted indole in 1 (Figure 1) was inferred by the existence of four characteristic signals in the low field region of the ${ }^{1} \mathrm{H}$ NMR spectrum in DMSO- $d_{6}$, two doublets at $\delta_{\mathrm{H}} 7.78(\mathrm{~d}, \mathrm{H}-2, J=2.4 \mathrm{~Hz})$ and $11.78(\mathrm{~d}, \mathrm{NH}-1, J=2.6 \mathrm{~Hz})$ and two singlets at $\delta_{\mathrm{H}} 7.81(\mathrm{~s}, \mathrm{H}-7)$ and $\delta_{\mathrm{H}} 8.01(\mathrm{~s}, \mathrm{H}-4)$. In addition, the two bromine atoms contained in the molecular formula were located at C-5 and C-6 based on their ${ }^{13} \mathrm{C}$ chemical shifts. The intense 3-bond long range couplings between $\mathrm{H}-4$ and C-6 at $\delta_{\mathrm{C}} 115.7$ ppm and between $\mathrm{H}-7$ and C-5 at $\delta_{\mathrm{C}} 113.5 \mathrm{ppm}$ observed in the HMBC spectrum further confirmed the chemical shifts of these two quaternary carbons. The nature of the substituent at C-3 was deduced from analysis of additional signals in the low field region of the ${ }^{1} \mathrm{H}$ NMR spectrum and correlations observed in the COSY, HSQC and HMBC spectra. A spin system comprising two olefinic signals at $\delta_{\mathrm{H}} 6.06 \mathrm{ppm}(\mathrm{H}-8)$ and $6.68 \mathrm{ppm}(\mathrm{H}-9)$, and an interchangeable proton at $\delta_{\mathrm{H}} 9.60 \mathrm{ppm}(\mathrm{NH}-10)$ established the presence of an enamide. A coupling constant of $9.4 \mathrm{~Hz}$ between $\mathrm{H}-8$ and $\mathrm{H}-9$ confirmed a $Z$ geometry for this double bond. Finally, HMBC correlations from $\mathrm{H}-9$ to $\mathrm{C}-3\left(\delta_{\mathrm{C}} 109.2 \mathrm{ppm}\right)$ and from $\mathrm{H}-8$ to $\mathrm{C}-2\left(\delta_{\mathrm{C}} 126.8 \mathrm{ppm}\right)$, and $\mathrm{C}-3 \mathrm{a}\left(\delta_{\mathrm{C}}\right.$ $127.6 \mathrm{ppm}$ ) indicated that the indole moiety was substituted at $\mathrm{C}-3$ with a $Z$ geometry enamide fragment. The remaining atoms, $\mathrm{C}_{6} \mathrm{H}_{9} \mathrm{~N}_{2} \mathrm{O}_{2} \mathrm{~S}_{2}$, comprised two carbonyl ( $\delta_{\mathrm{C}} 169.9$ and $\left.167.1 \mathrm{ppm}\right)$, two methine, $\left(\delta_{\mathrm{C}} 52.5 / \delta_{\mathrm{H}} 5.02 \mathrm{ppm}\right.$ and $\left.\delta_{\mathrm{C}} 51.2 / \delta_{\mathrm{H}} 4.65 \mathrm{ppm}\right)$ and two methylene groups $\left(\delta_{\mathrm{C}} 41.6 / \delta_{\mathrm{H}}\right.$ 3.40 and $2.86 \mathrm{ppm}$ and $\delta_{\mathrm{C}} 39.7 / \delta_{\mathrm{H}} 3.17$ and $2.94 \mathrm{ppm}$ ) with three degrees of unsaturation being required for this molecular formula, including the two carbonyls mentioned previously. Analysis of the 
bidimensional spectra revealed the presence of a two spin system corresponding to two consecutive cysteine residues. Cross-peaks observed in the HMBC experiment between H-12 and H-16 and carbon C-14 at $\delta_{\mathrm{C}} 169.9 \mathrm{ppm}$ (Figure 2) confirmed this structural proposal. Furthermore, correlations observed in the HMBC experiment between $\mathrm{H}-9, \mathrm{NH}-10, \mathrm{H}-12$ and $\mathrm{H}-17$ to $\mathrm{C}-11$, and a ROESY correlation between NH-10 and H-12, connected these cysteines residues to the enamide group through C-11. Finally, linkage of the two cysteine amino acids by a S-S bond to form a cyclic cystine explained the remaining unsaturation present and established the complete structure of Tanjungide A.

Table 1. ${ }^{1} \mathrm{H}$ and ${ }^{13} \mathrm{C}$ NMR (500 and $125 \mathrm{MHz}$ ) assignments for Tanjungide $\mathrm{A}$ (1) $\left(\mathrm{DMSO}-d_{6}\right)$ and Tanjungide $\mathrm{B}(\mathbf{2})\left(\mathrm{CD}_{3} \mathrm{OD}\right)$.

\begin{tabular}{ccccc}
\hline \multirow{2}{*}{ Position } & \multicolumn{2}{c}{ Tanjungide A (1) } & \multicolumn{2}{c}{ Tanjungide B (2) } \\
\cline { 2 - 5 } $\mathbf{1}$ & $\delta_{\mathbf{H}}(\mathbf{m}, \boldsymbol{J}$ in Hz) & $\delta_{\mathbf{C}}$, mult. & $\delta_{\mathbf{H}}(\mathbf{m}, \boldsymbol{J}$ in Hz) & $\delta_{\mathbf{C}}, \mathbf{m u l t}$. \\
$\mathbf{2}$ & $11.78(\mathrm{~d}, 2.6)$ & - & - & - \\
$\mathbf{3}$ & $7.78(\mathrm{~d}, 2.4)$ & $126.8, \mathrm{~d}$ & $7.35(\mathrm{~s})$ & $126.7, \mathrm{~d}$ \\
$\mathbf{3 a}$ & - & $109.2, \mathrm{~s}$ & - & $112.9, \mathrm{~s}$ \\
$\mathbf{4}$ & - & $127.6, \mathrm{~s}$ & - & $127.4, \mathrm{~s}$ \\
$\mathbf{5}$ & $8.01(\mathrm{~s})$ & $123.0, \mathrm{~d}$ & $8.04(\mathrm{~s})$ & $124.6, \mathrm{~d}$ \\
$\mathbf{6}$ & - & $113.5, \mathrm{~s}$ & - & $117.5, \mathrm{~s}$ \\
$\mathbf{7}$ & - & $115.7, \mathrm{~s}$ & - & $115.5, \mathrm{~s}$ \\
$\mathbf{7 a}$ & $7.81(\mathrm{~s})$ & $116.3, \mathrm{~d}$ & $7.72(\mathrm{~s})$ & $117.4, \mathrm{~d}$ \\
$\mathbf{8}$ & - & $135.4, \mathrm{~s}$ & - & $138.3, \mathrm{~s}$ \\
$\mathbf{9}$ & $6.06(\mathrm{~d}, 9.4)$ & $103.8, \mathrm{~d}$ & $6.50(\mathrm{~d}, 14.8)$ & $109.2, \mathrm{~d}$ \\
$\mathbf{1 0}$ & $6.68(\mathrm{dd}, 9.4,9.8)$ & $118.9, \mathrm{~d}$ & $7.34(\mathrm{~d}, 14.8)$ & $120.7, \mathrm{~d}$ \\
$\mathbf{1 1}$ & $9.60(\mathrm{~d}, 9.8)$ & - & - & - \\
$\mathbf{1 2}$ & - & $167.1, \mathrm{~s}$ & - & $167.8, \mathrm{~s}$ \\
$\mathbf{1 3}$ & $5.02(\mathrm{ddd}, 11.8,11.5,3.6)$ & $52.5, \mathrm{~d}$ & $4.93(\mathrm{~m})$ & $54.2, \mathrm{~d}$ \\
$\mathbf{1 4}$ & $8.44(\mathrm{br} \mathrm{s})$ & - & - & - \\
$\mathbf{1 5}$ & - & $169.9, \mathrm{~s}$ & - & $169.0, \mathrm{~s}$ \\
$\mathbf{1 6}$ & $4.65(\mathrm{~m})$ & $51.2, \mathrm{~d}$ & $4.60(\mathrm{~m})$ & $53.7, \mathrm{~d}$ \\
$\mathbf{1 7}$ & $2.94(\mathrm{dd}, 14.2,11.5)$ & $39.7, \mathrm{t}$ & $3.11(\mathrm{~m})$ & $41.8, \mathrm{t}$ \\
& $3.17(\mathrm{~m})$ & & & $43.2, \mathrm{t}$ \\
\hline
\end{tabular}

Figure 1. Chemical Structures of Tanjungides.

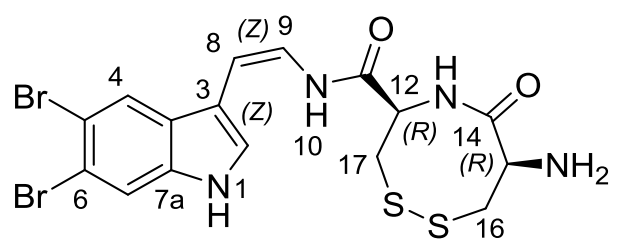

Tanjungide A (1)

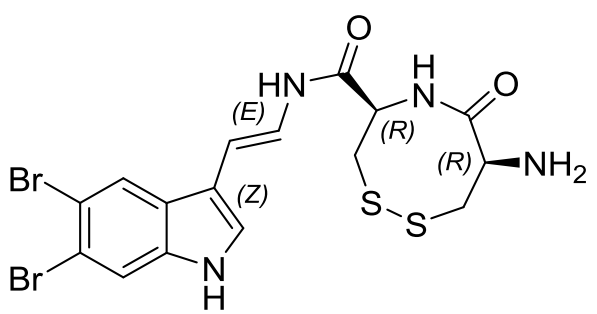

Tanjungide B (2) 
Figure 2. Selected HMBC (H $\rightarrow \mathrm{C}$, red) and ROESY (blue) correlations for Tanjungide A.

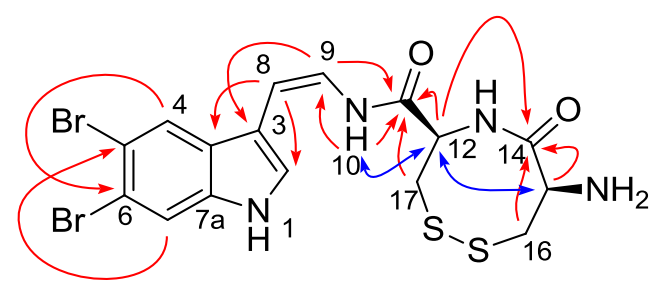

Tanjungide A

The absolute configuration of $\mathbf{1}$ was determined by converting the cyclized cystine into two alanines by Raney ${ }^{\circledR}$-Nickel desulfurization [12]. The absolute configuration of the resulting Ala amino acids was determined to be $R$ by comparing the hydrolysis products of $\mathbf{1}$ with appropriate amino acid standards using HPLC-MS chromatography and after derivatization with Marfey's reagent L-FDAA (No-(2,4-dinitro-5-fluorophenyl)-L-alaninamide) [13].

Compound 2 (Figure 1) was isolated as an optically active pale yellow amorphous solid with the same molecular formula as 1 [(+)-HRESIMS $m / z 518.9142[\mathrm{M}+\mathrm{H}]^{+}$(Calcd. for $\mathrm{C}_{16} \mathrm{H}_{17}{ }^{79} \mathrm{Br}_{2} \mathrm{~N}_{4} \mathrm{O}_{2} \mathrm{~S}_{2}$, 518.9154)]. After examination of the $1 \mathrm{D}$ and $2 \mathrm{D}$ NMR spectra we concluded that Tanjungide $\mathrm{B}$ (Table 1) was very similar to Tanjungide A, and the major difference found in the ${ }^{1} \mathrm{H}$ NMR was the value of the coupling constant of the $\Delta^{8}$ olefin signals. Thus, the coupling constant $J_{\mathrm{H} 8 \text {-H9 }}$ had a value of $14.6 \mathrm{~Hz}$ corresponding to a $E$ geometry for the double bond. The absolute configuration of the Cys residues was not determined due to the small amount of compound isolated and was assumed to be the same as in Tanjungide A (1). The validity of this assumption was later confirmed by total synthesis of the molecule.

\subsection{Biological Activities of Tanjungides $A$ and $B$}

The cytotoxic activity of the new compounds (Table 2) was tested against three human tumour cell lines, lung (A549), colon (HT29), and breast (MDA-MB-231), following a published procedure [14]. Tanjungide A (1) exhibited strong activity with $\mathrm{GI}_{50}$ values in the range 0.19 to $0.33 \mu \mathrm{M}$, whereas Tanjungide B (2) displayed only mild cytotoxicity, with $\mathrm{GI}_{50}$ values ranging from 1.00 to $2.50 \mu \mathrm{M}$.

Table 2. Cytotoxic Activity Data $(\mu \mathrm{M})$ of Compounds 1 and 2.

\begin{tabular}{cccc}
\hline \multirow{2}{*}{ Compound } & Lung-NSCLC & Colon & Breast \\
\cline { 2 - 4 } & $\mathbf{A 5 4 9}$ & HT29 & MDA-MB-231 \\
\cline { 2 - 4 } & $\mathbf{G I}_{\mathbf{5 0}}$ & $\mathbf{G I}_{\mathbf{5 0}}$ & GI $_{\mathbf{5 0}}$ \\
\hline Natural Tanjungide A & 0.33 & 0.19 & 0.23 \\
Synthetic Tanjungide A & 0.33 & 0.25 & 0.19 \\
Natural Tanjungide B & 2.50 & 2.31 & 1.63 \\
Synthetic Tanjungide B & 1.00 & 1.15 & 1.11 \\
\hline
\end{tabular}

\subsection{Total Synthesis of Tanjungides $A$ and $B$}

In order to solve the supply problem for these two new marine chemical entities and progress pharmaceutical development and in vivo preclinical studies, we have completed the first total synthesis 
of Tanjungides A and B. This synthesis uses methyl $1 H$-indole-3-carboxylate as starting material and involves a linear sequence of 11 chemical steps. Key elements of our approach include selective dibromination of the indole, formylation by Vilsmeier reaction, Wittig olefination, stereoselective enamide formation and oxidation to create the disulfide bond (Figure 3). The strategy uses vinyl iodide indole $\mathbf{8}$ as a common precursor to give both Tanjungides.

Figure 3. Retrosynthetic analysis of Tanjungides A and B.

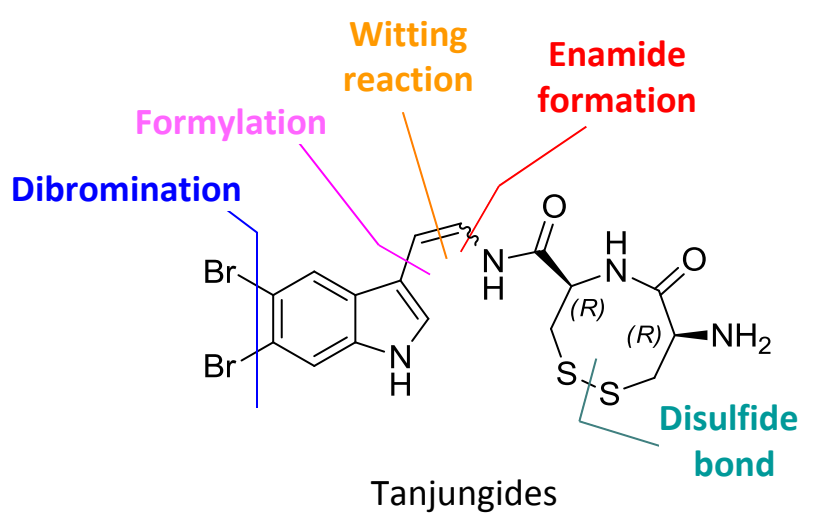

The synthesis started, as outlined in Scheme 1, from the cheap commercially available methyl $1 \mathrm{H}$-indole-3-carboxylate as this provided a high yielding route to a 5,6-dibrominated indole possessing an aldehyde moiety at $\mathrm{C} 3$, a highly versatile building block for the total synthesis of the two natural products. The slow addition of two equivalents of bromine to methyl $1 H$-indole-3-carboxylate in acetic acid at $23{ }^{\circ} \mathrm{C}$ yielded the corresponding 5,6-dibromo intermediate 3 as a single pure product in $66 \%$ yield [15]. Disappointingly, attempted methyl ester reduction of $\mathbf{3}$ to give aldehyde $\mathbf{6}$ directly was unsuccessful, and an alternative stepwise process to give aldehyde $\mathbf{6}$ was used involving hydrolysis and decarboxylation to give 5,6-dibromo- $1 H$-indole 5 in good yield (90\% over two steps) followed by Vilsmeier formylation using dimethylformamide and phosphorus oxychloride. After protection of the indole nitrogen as a tert-butyl carbamate, Wittig olefination with (iodomethyl)triphenylphosphonium iodide [16] gave the desired vinyl iodide indole 8 in $83 \%$ yield and as a 9:1 ratio of $Z$ : $E$ isomers [17].

With vinyl iodide $\mathbf{8}$ in hand, the next step involved coupling of the suitably-protected cysteine amino acids (Scheme 1). As described by Buchwald and co-workers [18], depending on the conditions used for the coupling reaction, vinyl iodide $\mathbf{8}$ provided access to both stereoisomers of enamide $\mathbf{1 0}$ and hence to both Tanjungide A and B. Specifically, copper-catalyzed reaction of $\mathbf{8}$ with $\mathrm{N}$-allyloxycarbonyl-S-trityl-L-cysteine-amide 9, made in one step from commercially available $S$-trityl-L-cysteine-amide, gave enamide 10 in moderate yield $(50 \%-60 \%)$ with use of $\mathrm{Cs}_{2} \mathrm{CO}_{3}$ as base affording mainly enamide $(Z)-\mathbf{1 0}$, which could be readily separated from the corresponding $(E)$-isomer by column chromatography, and $\mathrm{K}_{2} \mathrm{CO}_{3}$ providing predominantly enamide $(E)-\mathbf{1 0}$. Next, removal of the Alloc group of $(Z)$-10 or $(E)$-10 under neutral conditions using $\mathrm{Pd}\left(\mathrm{PPh}_{3}\right)_{4}$ and $\mathrm{PhSiH}_{3}$ and coupling of the resulting primary amine with ( $N$-(tert-butoxycarbonyl)-S-trityl-L-cysteine) by treatment with HATU and HOBt yielded the corresponding amide $(Z)-\mathbf{1 2}$ or $(E)-\mathbf{1 2}$. After substantial experimentation, the trityl group proved to be the best thiol protecting group for each of the cysteine amino acid building blocks. To complete the synthesis, the key cyclization of $\mathbf{1 2}$ to form the disulfide bond was accomplished using $\mathrm{I}_{2}$ in $\mathrm{CH}_{2} \mathrm{Cl}_{2}: \mathrm{CH}_{3} \mathrm{OH}$ at high dilution to avoid undesired side-products $[19,20]$ and 
subsequent simultaneously cleavage of both Boc protecting groups of $\mathbf{1 3}$ with TFA gave Tanjungides A (1) and B (2). All the spectroscopic data $\left({ }^{1} \mathrm{H}\right.$ and ${ }^{13} \mathrm{C}$ NMR, optical rotation, IR, etc.), HPLC retention times and biological activities of the synthetic samples exactly matched those of the isolated natural products. The Supplementary Information provides more details.

Scheme 1. Total synthesis of Tanjungides A (1) and B (2).
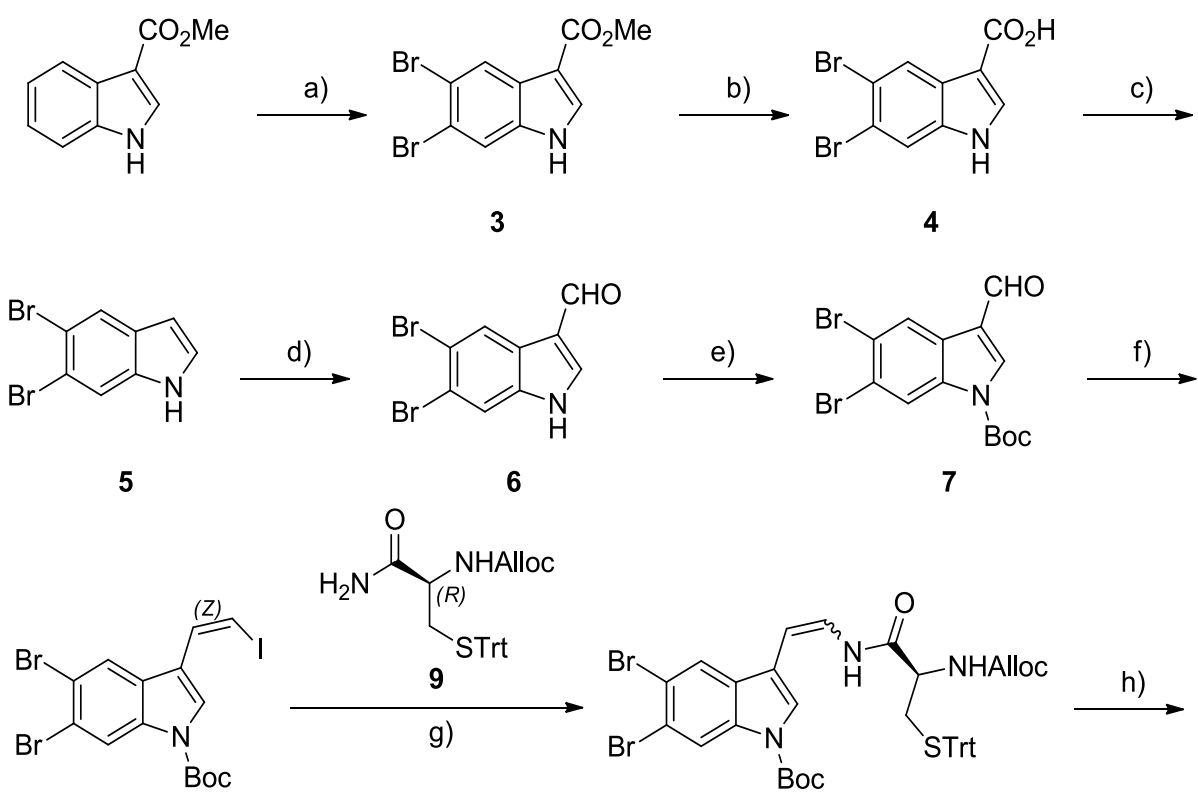

8<smiles></smiles>

(Z)-11

(E)-11

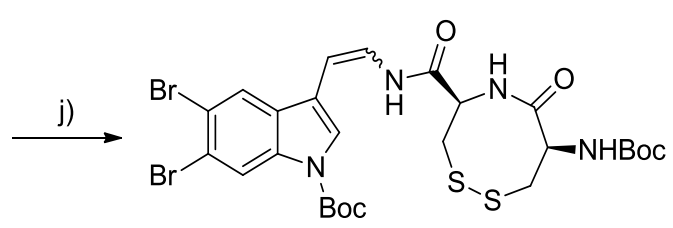

(Z)-13

(E)-13

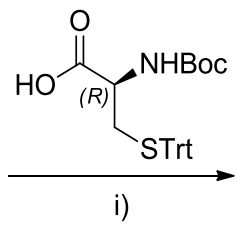

(E)-10<smiles>CCC[Sn]C[C@H](NC(=O)OC(C)(C)C)C(=O)N[C@@H](C[Sn])C(=O)N/C=C\c1cn(C(=O)OC(C)(C)C)c2cc(Br)c(Br)cc12</smiles>

(Z)-12

(E)-12

Regents and conditions: (a) $\mathrm{Br}_{2}, \mathrm{AcOH}, 23{ }^{\circ} \mathrm{C}, 2 \mathrm{~h}, 66 \%$; (b) aq $\mathrm{NaOH} 2 \mathrm{M}, \mathrm{CH}_{3} \mathrm{OH}$, reflux, $2.5 \mathrm{~h}, 95 \%$; (c) Pyridine, reflux, $12 \mathrm{~h}, 95 \%$; (d) $i \mathrm{POCl}_{3}, \mathrm{DMF}, 35^{\circ} \mathrm{C}, 1 \mathrm{~h}$ then $65{ }^{\circ} \mathrm{C}, 1 \mathrm{~h}$, ii aq NaOH $2 \mathrm{M}, 110{ }^{\circ} \mathrm{C}$, 5 min, 92\%; (e) (Boc) ${ }_{2} \mathrm{O}$, DMAP, 1,4-Dioxane, $23{ }^{\circ} \mathrm{C}, 2$ h, 86\%; (f) Iodomethyltriphpenylphosphonium iodide, NaHMDS $1.0 \mathrm{M}$, THF, $-78^{\circ} \mathrm{C}, 2 \mathrm{~h}, 83 \%$; (g) for (Z)-10: 9, Cul, $\mathrm{Cs}_{2} \mathrm{CO}_{3}$, DMEDA, THF, $60{ }^{\circ} \mathrm{C}, 18 \mathrm{~h}$, 50\% + 13\% (E)-10; for (E)-10: 9, Cul, $\mathrm{K}_{2} \mathrm{CO}_{3}$, DMEDA, THF, $80{ }^{\circ} \mathrm{C}, 18 \mathrm{~h}, 60 \%+14 \%(Z)-10$; (h) $\mathrm{Pd}\left(\mathrm{PPh}_{3}\right)_{4}, \mathrm{PhSiH}_{3}, \mathrm{CH}_{2} \mathrm{Cl}_{2}, 23{ }^{\circ} \mathrm{C}, 30 \mathrm{~min}, 85 \%(Z)-11$ and 72\% (E)-11; (i) $N$-Boc-L-( $S$-trityl)-Cys, HATU, HOBt, DIPEA, $\mathrm{CH}_{2} \mathrm{Cl}_{2}$ :DMF (4:1), $23{ }^{\circ} \mathrm{C}, 2 \mathrm{~h}, 83 \%(Z)-12$ and $62 \%(E)-12$; (j) $\mathrm{I}_{2}, \mathrm{CH}_{2} \mathrm{Cl}_{2}: \mathrm{CH}_{3} \mathrm{OH}$ (10:1), $23{ }^{\circ} \mathrm{C}, 40 \mathrm{~min}, 84 \%(Z)-\mathbf{1 3}$ and $73 \%(E)-13$; (k) TFA, $\mathrm{CH}_{2} \mathrm{Cl}_{2}, 0{ }^{\circ} \mathrm{C}, 3 \mathrm{~h}, 60 \%(Z)$-Tanjungide $\mathrm{A}$ and $45 \%(E)$-Tanjungide $\mathbf{B}$. 


\section{Experimental Section}

\subsection{General}

Dry solvents were purchased and used without any extra processing. All reagents were used as purchased without further purification unless otherwise stated. All reactions were performed under an atmosphere of nitrogen in flame dried or oven dried glassware. Routine monitoring of reactions was performed using silica gel TLC plates (Merck 60 F254, Merck KGaA, Darmstadt, Germany). Spots were visualized by UV and/or dipping the TLC plate into an ethanolic phosphomolybdic acid solution and heating with a hot plate. Flash chromatography was carried out on silica gel 60 (200-400 mesh). ${ }^{1} \mathrm{H}$ and ${ }^{13} \mathrm{C}$ NMR were recorded on a Varian Unity 300 or 500 spectrometer at 300 or 500 , and 75 or $125 \mathrm{MHz}$, respectively. Chemical Shifts $(\delta)$ are reported in parts per millions (ppm) referenced to $\mathrm{CHCl}_{3}$ at $7.26 \mathrm{ppm}$ for ${ }^{1} \mathrm{H}$ and $\mathrm{CDCl}_{3}$ at $77.0 \mathrm{ppm}$ for ${ }^{13} \mathrm{C}$, to $\mathrm{CH}_{3} \mathrm{OH}$ at $3.30 \mathrm{ppm}$ for ${ }^{1} \mathrm{H}$ and $\mathrm{CD}_{3} \mathrm{OD}$ at $49.0 \mathrm{ppm}$; and to $\left(\mathrm{CH}_{3}\right)_{2} \mathrm{SO}$ at $2.50 \mathrm{ppm}$ for ${ }^{1} \mathrm{H}$ and $\left(\mathrm{CD}_{3}\right)_{2} \mathrm{SO}$ at $39.5 \mathrm{ppm}$ for ${ }^{13} \mathrm{C}$. Coupling constants are reported in Hertz $(\mathrm{Hz})$, with the following abbreviations used: $\mathrm{s}=$ singlet, $\mathrm{d}=$ doublet, $\mathrm{t}=$ triplet, $\mathrm{q}=$ quartet, $\mathrm{m}=$ multiplet. When appropriate, the multiplicities are preceded with $\mathrm{br}$, indicating that the signal was broad. Optical rotations were determined using a Jasco P-1020 polarimeter (Jasco Inc., Easton, MD, USA) with a sodium lamp and are reported as follows: $[\alpha]_{\mathrm{D}}^{25}(\mathrm{c} \mathrm{g} / 100 \mathrm{~mL}$, solvent). (+)-HRESIMS was performed on an Applied Biosystems QStar pulsar Analyzer spectrometer (Applied Biosystems Inc., Foster City, CA, USA) employing 0.1\% of formic acid in methanol as an ionic mobile phase. (+)-ESIMS were recorded using an Agilent 1100 Series LC/MSD spectrometer (Agilent Technologies, Santa Clara, CA, USA). UV spectra were performed using an Agilent 8453 UV-VIS spectrometer (Agilent Technologies). IR spectra were obtained with a Perkin Elmer Spectrum 100 FT-IR spectrometer (PerkinElmer Inc., Waltham, MA, USA) with ATR sampling.

\subsection{Animal Material}

The tunicate Diazona cf formosa (Order Phlebobranchia, Family Diazonidae, Genus Diazona) was collected by hand using a rebreather diving system in East Timor $\left(08^{\circ} 25.637^{\prime} S / 126^{\circ} 22.849^{\prime} E\right)$ at depths ranging between 6 and $80 \mathrm{~m}$ in June 2009. A sample of the specimen was deposited in the Center for the Advanced Studies of Blanes in Girona, Spain, with the reference code TISM-763.

\subsection{Extraction and Isolation}

A specimen of Diazona cf formosa (128 g) was triturated and exhaustively extracted with $\mathrm{CH}_{3} \mathrm{OH}: \mathrm{CH}_{2} \mathrm{Cl}_{2}(50: 50,3 \times 200 \mathrm{~mL})$. The combined extracts were concentrated to yield a crude mass of $5.05 \mathrm{~g}$ that was subjected to VLC on Lichroprep RP-18 (Merck KGaA) with a stepped gradient from $\mathrm{H}_{2} \mathrm{O}$ to $\mathrm{CH}_{3} \mathrm{OH}$ and then $\mathrm{CH}_{3} \mathrm{OH}: \mathrm{CH}_{2} \mathrm{Cl}_{2}$ (50:50). Fraction eluted with $\mathrm{CH}_{3} \mathrm{OH}: \mathrm{H}_{2} \mathrm{O}(75: 25,63.7 \mathrm{mg})$ were subjected to preparative HPLC (Symmetry C18, $7 \mu \mathrm{m}, 19 \times 150 \mathrm{~mm}$, gradient $\mathrm{H}_{2} \mathrm{O}+0.1 \%$ TFA: $\mathrm{CH}_{3} \mathrm{CN}+0.1 \%$ TFA from $32 \%$ to $49 \% \mathrm{CH}_{3} \mathrm{CN}+0.1 \%$ TFA in $14 \mathrm{~min}$ and then from $49 \%$ to $100 \%$ in $1 \mathrm{~min}$, flow: $13.6 \mathrm{~mL} / \mathrm{min}$, UV detection) to yield Tanjungide A (31.8 $\mathrm{mg}$, retention time: $10.1 \mathrm{~min})$ and Tanjungide $\mathrm{B}(1.6 \mathrm{mg}$, retention time: $9.2 \mathrm{~min})$. Fraction eluted with $\mathrm{CH}_{3} \mathrm{OH}$ 
(100.7 mg), was also subjected to the same conditions of preparative HPLC to yield additional amounts of Tanjungides $\mathrm{A}$ and $\mathrm{B}$.

Tanjungide A (1): Pale yellow amorphous solid. $[\alpha]^{25}{ }_{\mathrm{D}}+114.9^{\circ}\left(c 0.1, \mathrm{CH}_{3} \mathrm{OH}\right)$; $\mathrm{UV}\left(\mathrm{CH}_{3} \mathrm{OH}\right) \lambda_{\max }$ 201, 236, $288 \mathrm{~nm}$; IR (KBr) $v_{\max }$ 3324, 1674, 1534, 1494, 1450, 1203, 1144, 803, $723 \mathrm{~cm}^{-1}$; (+)-HRESIMS $m / z 518.9142[\mathrm{M}+\mathrm{H}]^{+}$(Calcd. for $\mathrm{C}_{16} \mathrm{H}_{17}{ }^{79} \mathrm{Br}_{2} \mathrm{~N}_{4} \mathrm{O}_{2} \mathrm{~S}_{2}$, 518.9154). ${ }^{1} \mathrm{H}$ NMR $(500 \mathrm{MHz})$ and ${ }^{13} \mathrm{C}$ NMR $(125 \mathrm{MHz})$ in DMSO- $d_{6}$, see Table 1.

Tanjungide B (2): Pale yellow amorphous solid. $[\alpha]^{25}+46.2^{\circ}\left(c 0.1, \mathrm{CH}_{3} \mathrm{OH}\right) ; \mathrm{UV}\left(\mathrm{CH}_{3} \mathrm{OH}\right) \lambda_{\max }$ 201, 236, $291 \mathrm{~nm}$; IR (KBr) $v_{\max }$ 3296, 1676, 1571, 1447, 1203, 1141, 803, $726 \mathrm{~cm}^{-1}$; (+)-HRESIMS $m / z 518.9142[\mathrm{M}+\mathrm{H}]^{+}$(Calcd. for $\left.\mathrm{C}_{16} \mathrm{H}_{17}{ }^{79} \mathrm{Br}_{2} \mathrm{~N}_{4} \mathrm{O}_{2} \mathrm{~S}_{2}, 518.9154\right) .{ }^{1} \mathrm{H}$ NMR $(500 \mathrm{MHz})$ and ${ }^{13} \mathrm{C}$ NMR (125 MHz) in $\mathrm{CD}_{3} \mathrm{OD}$, see Table 1.

\subsection{Absolute Configuration of Cysteine Residues}

Approximately $100 \mu \mathrm{L}$ of Raney ${ }^{\circledR}$-Nickel (50\% slurry in $\mathrm{H}_{2} \mathrm{O}$, excess) was added to Tanjungide A (1.02 $\mathrm{mg}$ ) in methanol $(1.2 \mathrm{~mL}), \mathrm{N}_{2}$ was bubbled through the solution to remove $\mathrm{O}_{2}$. The resulting suspension was heated at $65^{\circ} \mathrm{C}$ for $4 \mathrm{~h}$ under nitrogen and then the reaction mixture was left overnight at $23{ }^{\circ} \mathrm{C}$. The disappearance of starting material was monitored by HPLC. The resulting solution was purified on a C18 SPE cartridge using methanol as eluent, yielding desthiotanjungide A. Desthiotanjungide A $(200 \mu \mathrm{g})$ was dissolved in $6 \mathrm{~N} \mathrm{HCl}(500 \mu \mathrm{L})$ and heated in a sealed glass vial at $110{ }^{\circ} \mathrm{C}$ overnight. The solvent was removed in a stream of dry $\mathrm{N}_{2}$. To the acid hydrolysate of desthiotanjungide A, a solution of L-FDAA ( $N \alpha$-(2,4-dinitro-5-fluorophenyl)-L-alaninamide, $700 \mu \mathrm{g}$ ) in acetone $(160 \mu \mathrm{L}), \mathrm{H}_{2} \mathrm{O}(100 \mu \mathrm{L})$ and $\mathrm{NaHCO}_{3} 1 \mathrm{~N}(50 \mu \mathrm{L})$ were added. The vials were heated at $40{ }^{\circ} \mathrm{C}$ for $1 \mathrm{~h}$, and the contents neutralized with $2 \mathrm{~N} \mathrm{HCl}(20 \mu \mathrm{L})$ after cooling to $23{ }^{\circ} \mathrm{C} . \mathrm{H}_{2} \mathrm{O}(800 \mu \mathrm{L})$ was added to each reaction and the resulting mixture filtered and analyzed by RP18-HPLC-MS (Symmetry C18, $5 \mu \mathrm{m}, 4.6 \times 150 \mathrm{~mm}$; linear gradient from $20 \%$ to $50 \% \mathrm{CH}_{3} \mathrm{CN}(0.04 \% \mathrm{TFA})$ in $\mathrm{H}_{2} \mathrm{O}$ $(0.04 \%$ TFA) over $20 \mathrm{~min}$, flow rate: $0.8 \mathrm{~mL} / \mathrm{min})$. The amino acid standards $(R)$ - and $(S)$-Ala $(200 \mu \mathrm{g})$ were derivatized in a similar manner, and the retention times were compared with those of the alanines of desthiotanjungide A hydrolysate. The retention times of the authentic FDAA-Ala used as standards were as follows: $(S)$-Ala $(13.9 \mathrm{~min})$ and $(R)$-Ala $(16.3 \mathrm{~min})$. The hydrolysate of Tanjungide A contained: $(S)$-Ala (13.7 $\mathrm{min})$.

\subsection{Total Synthesis of Tanjungides $A$ (1) and B (2)}

\subsubsection{5,6-Dibromo-1H-indole-3-carboxylic Acid (4)}

To a stirred solution of methyl 5,6-dibromo- $1 H$-indole-3-carboxylate (3) (12.5 g, $37.8 \mathrm{mmol})$ in $\mathrm{CH}_{3} \mathrm{OH}(124 \mathrm{~mL})$ was added an aqueous solution of $\mathrm{NaOH}(188 \mathrm{~mL}, 2 \mathrm{M}, 376 \mathrm{mmol})$. The suspension was refluxed for $2.5 \mathrm{~h}$. After this time, the brown solution was cooled to $23{ }^{\circ} \mathrm{C}$ and the volatiles were evaporated. The aqueous phase was acidified with a $1 \mathrm{M}$ solution of $\mathrm{HCl}$ until reached $\mathrm{pH} 2$ and extracted with EtOAc. The combined organic layers were washed with brine, dried over $\mathrm{Na}_{2} \mathrm{SO}_{4}$, filtered and concentrated in vacuo to afford crude 4 (11.4 g, 95\% yield) as a brown solid which was used in the next step without further purification. ${ }^{1} \mathrm{H}$ NMR $\left(300 \mathrm{MHz}, \mathrm{CD}_{3} \mathrm{OD}\right) \delta_{\mathrm{H}} \mathrm{ppm}$ : $8.36(\mathrm{~s}, 1 \mathrm{H})$, 
$7.97(\mathrm{~s}, 1 \mathrm{H}), 7.79(\mathrm{~s}, 1 \mathrm{H}) .{ }^{13} \mathrm{C} \mathrm{NMR}\left(75 \mathrm{MHz}, \mathrm{CD}_{3} \mathrm{OD}\right) \delta_{\mathrm{C}} \mathrm{ppm}: 166.9,136.6,134.0,127.2,125.2$, 117.2, 116.7, 116.5, 107.5.

\subsubsection{5,6-Dibromo-1H-indole (5)}

5,6-Dibromo-1H-indole-3-carboxylic acid (4) (11.7 g, $36.7 \mathrm{mmol}$ ) was dissolved in pyridine $(20.5 \mathrm{~mL})$ and refluxed overnight. The solvent was concentrated in vacuo, the crude obtained was dissolved in $\mathrm{CH}_{2} \mathrm{Cl}_{2}$, precipitated with hexane and left at $5{ }^{\circ} \mathrm{C}$ overnight. The solid was filtered to yield crude 5 (9.6 g, 95\% yield) which was used in the next step without further purification. ${ }^{1} \mathrm{H}$ NMR $\left(300 \mathrm{MHz}, \mathrm{CDCl}_{3}\right) \delta_{\mathrm{H}} \mathrm{ppm}: 7.90(\mathrm{~d}, J=1.1 \mathrm{~Hz}, 1 \mathrm{H}), 7.70(\mathrm{t}, J=1.1 \mathrm{~Hz}, 1 \mathrm{H}), 7.21$ (ddd, $J=3.6,2.5$, $1.2 \mathrm{~Hz}, 1 \mathrm{H}), 6.48(\mathrm{ddt}, J=3.3,2.2,1.1 \mathrm{~Hz}, 1 \mathrm{H}) .{ }^{13} \mathrm{C} \mathrm{NMR}\left(75 \mathrm{MHz}, \mathrm{CDCl}_{3}\right) \delta_{\mathrm{C}} \mathrm{ppm:} \mathrm{135.7,} \mathrm{129.0,}$ $126.3,125.1,117.3,115.9,115.3,102.6$.

\subsubsection{5,6-Dibromo-1H-indole-3-carbaldehyde (6)}

To a stirred solution of DMF $(46.8 \mathrm{~mL})$ at $0{ }^{\circ} \mathrm{C}$ was dropwise added $\mathrm{POCl}_{3}(12.0 \mathrm{~mL}, 131.3 \mathrm{mmol})$. The mixture was further stirred for $5 \mathrm{~min}$ at $0{ }^{\circ} \mathrm{C}$ and a solution of 5,6-dibromo- $1 H$-indole (5) (7.22 g, $26.3 \mathrm{mmol})$ in DMF $(70 \mathrm{~mL})$ was slowly added. The reaction mixture was stirred $1 \mathrm{~h}$ at $35^{\circ} \mathrm{C}, 1 \mathrm{~h}$ at $65{ }^{\circ} \mathrm{C}$, and was left to reach $23^{\circ} \mathrm{C}$. An aqueous solution of $\mathrm{NaOH}(72.3 \mathrm{~mL}, 2 \mathrm{~N})$ was added at $0{ }^{\circ} \mathrm{C}$ and the reaction mixture was stirred $5 \mathrm{~min}$ at $110^{\circ} \mathrm{C}$, left to reach $23{ }^{\circ} \mathrm{C}$, and then added over an ice-water bath in order to precipitate 6 . The reaction mixture was left overnight at $5{ }^{\circ} \mathrm{C}$ and filtered to obtain crude 6 (7.32 g, 92\% yield) which was used in the next step without further purification. ${ }^{1} \mathrm{H}$ NMR (300 MHz, DMSO- $\left.d_{6}\right) \delta_{\mathrm{H}}$ ppm: $9.91(\mathrm{~d}, J=1.3 \mathrm{~Hz}, 1 \mathrm{H}), 8.51-8.20(\mathrm{~m}, 2 \mathrm{H}), 7.91(\mathrm{~d}, J=1.3 \mathrm{~Hz}, 1 \mathrm{H}) .{ }^{13} \mathrm{C}$ NMR $\left(75 \mathrm{MHz}, \mathrm{DMSO}-d_{6}\right) \delta_{\mathrm{C}}$ ppm: $185.9,140.7,137.4,125.7,125.4,118.2,118.1,117.8,117.4$.

\subsection{4. tert-Butyl 5,6-dibromo-3-formyl-1H-indole-1-carboxylate (7)}

To a stirred solution of 5,6-dibromo- $1 H$-indole-3-carbaldehyde (6) (9.2 g, $30.4 \mathrm{mmol})$ in 1,4-dioxane $(152 \mathrm{~mL})$ was added successively di-tert-butyldicarbonate (7.9 g, $36.4 \mathrm{mmol})$ and DMAP ( $370 \mathrm{mg}, 3.0 \mathrm{mmol}$ ). After stirring for $2 \mathrm{~h}$ at $23{ }^{\circ} \mathrm{C}$, the mixture was quenched with $\mathrm{H}_{2} \mathrm{O}$ and extracted with EtOAc. The combined organic phases were washed thoroughly with $\mathrm{H}_{2} \mathrm{O}$, dried over $\mathrm{Na}_{2} \mathrm{SO}_{4}$, filtered and concentrated in vacuo to afford 7 (10.5 g, 86\% yield) as a slightly brown solid that was used in the next steps without further purification. ${ }^{1} \mathrm{H}$ NMR $\left(300 \mathrm{MHz}, \mathrm{CDCl}_{3}\right) \delta_{\mathrm{H}} \mathrm{ppm}: 10.03(\mathrm{~s}, 1 \mathrm{H})$, $8.54(\mathrm{~s}, 1 \mathrm{H}), 8.47(\mathrm{~s}, 1 \mathrm{H}), 8.18(\mathrm{~s}, 1 \mathrm{H}), 1.71(\mathrm{~s}, 9 \mathrm{H}) .{ }^{13} \mathrm{C} \mathrm{NMR}\left(75 \mathrm{MHz}, \mathrm{CDCl}_{3}\right) \delta_{\mathrm{C}} \mathrm{ppm}: 185.2,148.3$, $137.2,135.5,126.7,126.6,122.2,120.9,120.6,120.4,86.9,28.2$.

\subsection{5. (Z)-tert-Butyl 5,6-dibromo-3-(2-iodovinyl)-1H-indole-1-carboxylate (8)}

To a suspension of iodomethyltriphpenylphosphonium iodide (14.6 g, $27.5 \mathrm{mmol})$ in anhydrous THF (157 mL) was added a solution of sodium bis(trimethylsilyl)amide (NaHMDS) $(27.5 \mathrm{~mL}, 1.0 \mathrm{M}$ in THF, $27.5 \mathrm{mmol}$ ) dropwise at $23{ }^{\circ} \mathrm{C}$. After stirring for $2 \mathrm{~min}$, the yellow mixture was cooled to $-78{ }^{\circ} \mathrm{C}$ and a solution of $7(7.9 \mathrm{~g}, 19.6 \mathrm{mmol})$ in anhydrous THF $(98 \mathrm{~mL})$ was then added. The reaction mixture was stirred at $-78{ }^{\circ} \mathrm{C}$ for $2 \mathrm{~h}$, at $23{ }^{\circ} \mathrm{C}$ for $5 \mathrm{~min}$, diluted with hexane, and filtered through a plug of Celite ${ }^{\circledR}$. The plug was rinsed with hexane, the combined filtrates were evaporated 
under reduced pressure affording 8 (8.62 $\mathrm{g}, 83 \%$ yield) as a brown solid that was used in the next steps without further purification. ${ }^{1} \mathrm{H}$ NMR $\left(300 \mathrm{MHz} \mathrm{CDCl}_{3}\right) \delta_{\mathrm{H}} \mathrm{ppm}: 8.56(\mathrm{~s}, 1 \mathrm{H}), 8.48(\mathrm{~s}, 1 \mathrm{H}), 7.80$ $(\mathrm{s}, 1 \mathrm{H}), 7.43(\mathrm{~d}, 1 \mathrm{H}, J=8.7 \mathrm{~Hz}), 6.67(\mathrm{~d}, 1 \mathrm{H}, J=8.7 \mathrm{~Hz}), 1.69(\mathrm{~s}, 9 \mathrm{H}) .{ }^{13} \mathrm{C} \mathrm{NMR}\left(75 \mathrm{MHz}, \mathrm{CDCl}_{3}\right) \delta_{\mathrm{C}}$ ppm: 149.1, 135.5, 130.6, 128.5, 125.0, 124.0, 123.1, 120.5, 118.8, 116.4, 85.4, 81.0, 28.3.

\subsection{6. (R)-Allyl (1-amino-1-oxo-3-(tritylthio)propan-2-yl)carbamate (9)}

To a stirred solution of $S$-trityl-L-cysteine amide $(500 \mathrm{mg}, 1.38 \mathrm{mmol})$ in a mixture $\mathrm{THF}: \mathrm{H}_{2} \mathrm{O}$ (2.5 mL:1.25 mL) at $0{ }^{\circ} \mathrm{C}$ was added solid $\mathrm{NaHCO}_{3}(232 \mathrm{mg}, 2.76 \mathrm{mmol})$ followed by allyloxycarbonyl chloride $(0.14 \mathrm{~mL}, 1.65 \mathrm{mmol})$. After stirring for $2 \mathrm{~h}$ at $0{ }^{\circ} \mathrm{C}$, the mixture was quenched by slow addition of a $2 \mathrm{M}$ solution of $\mathrm{HCl}$ until reached $\mathrm{pH} 2$ and extracted with $\mathrm{CH}_{2} \mathrm{Cl}_{2}$. The combined organic layers were dried over $\mathrm{Na}_{2} \mathrm{SO}_{4}$, filtered and the solvent was removed under reduced pressure to afford 9 as a white solid $(616 \mathrm{mg}, 100 \%$ yield) that was used without further purification. ${ }^{1} \mathrm{H}$ NMR $\left(300 \mathrm{MHz}, \mathrm{CDCl}_{3}\right) \delta_{\mathrm{H}} \mathrm{ppm}: 7.43(\mathrm{~m}, 5 \mathrm{H}), 7.33-7.19(\mathrm{~m}, 10 \mathrm{H}), 5.88(\mathrm{~m}, 1 \mathrm{H})$, 5.81 (br s, 1H), 5.33 (br s, 1H), 5.29 (d, 1H, 16.0 Hz), $5.22(\mathrm{~d}, 1 \mathrm{H}, J=10.5 \mathrm{~Hz}), 5.06$ (d, 1H, $J=7.2$ $\mathrm{Hz}), 4.52(\mathrm{dd}, 2 \mathrm{H}, 5.7, J=1.2 \mathrm{~Hz}), 3.87(\mathrm{~m}, 1 \mathrm{H}), 2.76(\mathrm{dd}, 1 \mathrm{H}, J=13.2,7.2 \mathrm{~Hz}), 2.57(\mathrm{dd}, 1 \mathrm{H}, J=13.2$, $5.1 \mathrm{~Hz}) .{ }^{13} \mathrm{C}$ NMR $\left(75 \mathrm{MHz}, \mathrm{CDCl}_{3}\right) \delta_{\mathrm{C}} \mathrm{ppm}: 172.4,156.0,144.5,132.5,129.8,128.3,127.2,118.2$, $67.6,66.3,53.7,33.9$.

\subsection{7. (R,Z)-tert-Butyl 3-(2-(2-(((allyloxy)carbonyl)amino)-3-(tritylthio)propanamido)vinyl)-5,} 6-dibromo- $1 H$-indole-1-carboxylate $(Z-10)$

A Schlenk tube was charged with copper(I) iodide $(39 \mathrm{mg}, 0.20 \mathrm{mmol})$, cesium carbonate (667 $\mathrm{mg}$, $2.05 \mathrm{mmol}$ ) and $N$-alloc- $S$-trityl-L-cysteine-amide (9) (455 mg, $1.02 \mathrm{mmol})$, evacuated and filled with $\mathrm{N}_{2} . N, N^{\prime}$-dimethylethylenediamine $(44 \mu \mathrm{L}, 0.41 \mathrm{mmol})$, vinyl iodide 8 (360 $\left.\mathrm{mg}, 0.68 \mathrm{mmol}\right)$ and dry THF ( $4 \mathrm{~mL}$ ) were added. The Schlenk tube was sealed, heated at $60{ }^{\circ} \mathrm{C}$ for $18 \mathrm{~h}$ and cooled to $23{ }^{\circ} \mathrm{C}$. The resultant mixture was diluted with EtOAc and quenched with $\mathrm{H}_{2} \mathrm{O}$. The organic layer was washed with $\mathrm{H}_{2} \mathrm{O}$ and dried over $\mathrm{Na}_{2} \mathrm{SO}_{4}$. The solvent was removed under reduced pressure and the residue was purified by flash chromatography on silica gel (hexane:EtOAc, 4:1) to yield successively pure (Z)-10 (285 mg, 50\% yield) and (E)-10 (77 mg, 13\% yield) as brown solids. ${ }^{1} \mathrm{H}$ NMR (300 MHz, $\left.\mathrm{CDCl}_{3}\right) \delta_{\mathrm{H}}$ ppm: $8.46(\mathrm{~s}, 1 \mathrm{H}), 8.21(\mathrm{~d}, 1 \mathrm{H}, J=8.1 \mathrm{~Hz}), 7.73(\mathrm{~s}, 1 \mathrm{H}), 7.61(\mathrm{~s}, 1 \mathrm{H}), 7.34(\mathrm{~m}, 5 \mathrm{H}), 7.22$ $(\mathrm{m}, 10 \mathrm{H}), 6.96(\mathrm{dd}, 1 \mathrm{H}, J=11.1,9.3 \mathrm{~Hz}), 5.78(\mathrm{~m}, 1 \mathrm{H}), 5.68(\mathrm{~d}, 1 \mathrm{H}, J=9.6 \mathrm{~Hz}), 5.21(\mathrm{~d}, 1 \mathrm{H}$, $J=17.1 \mathrm{~Hz}), 5.14(\mathrm{~d}, 1 \mathrm{H}, J=10.5 \mathrm{~Hz}), 4.90(\mathrm{~d}, 1 \mathrm{H}, J=7.2 \mathrm{~Hz}), 4.40(\mathrm{~m}, 2 \mathrm{H}), 3.83(\mathrm{~m}, 1 \mathrm{H}), 2.83(\mathrm{dd}$, $1 \mathrm{H}, J=13.2,6.9 \mathrm{~Hz}), 2.58(\mathrm{dd}, 1 \mathrm{H}, J=13.2,5.7 \mathrm{~Hz}), 1.68(\mathrm{~s}, 9 \mathrm{H}) .{ }^{13} \mathrm{C} \mathrm{NMR}\left(75 \mathrm{MHz}, \mathrm{CDCl}_{3}\right) \delta_{\mathrm{C}}$ ppm: 168.1, 156.4, 149.0, 144.4, 134.7, 132.4, 130.4, 129.7, 128.3, 127.1, 124.7, 123.8, 123.3, 120.8, $120.5,118.8,118.2,114.3,100.2,85.2,67.7,66.5,54.1,32.9,28.3$.

3.5.8. (R,E)-tert-Butyl 3-(2-(2-(((allyloxy)carbonyl)amino)-3-(tritylthio)propanamido)vinyl)-5, 6-dibromo-1H-indole-1-carboxylate $(E-10)$

A Schlenk tube was charged with copper(I) iodide $(11 \mathrm{mg}, 0.06 \mathrm{mmol})$, potassium carbonate (78 mg, $0.57 \mathrm{mmol}$ ) and $N$-alloc-S-trityl-L-cysteine-amide (9) $(127 \mathrm{mg}, 0.284 \mathrm{mmol})$, evacuated and filled with $\mathrm{N}_{2}$. $N, N^{\prime}$-dimethylethylenediamine (12 $\left.\mu \mathrm{L}, 0.11 \mathrm{mmol}\right)$, vinyl iodide 8 (100 mg, $\left.0.19 \mathrm{mmol}\right)$ 
and dry THF ( $5 \mathrm{~mL})$ were added. The Schlenk tube was sealed, heated at $80{ }^{\circ} \mathrm{C}$ for $18 \mathrm{~h}$ and cooled to $23{ }^{\circ} \mathrm{C}$. The resultant mixture was diluted with EtOAc and quenched with $\mathrm{H}_{2} \mathrm{O}$. The organic layer was washed with $\mathrm{H}_{2} \mathrm{O}$ and dried over $\mathrm{Na}_{2} \mathrm{SO}_{4}$. The solvent was removed under reduced pressure and the residue was purified by flash chromatography on silica gel (hexane:EtOAc, 4:1) to yield pure $(E)-10$ (96 mg, 60\% yield) and (Z)-10 (22 mg, 14\% yield) as brown solids. ${ }^{1} \mathrm{H}$ NMR $\left(300 \mathrm{MHz}, \mathrm{CDCl}_{3}\right) \delta_{\mathrm{H}}$ ppm: $8.50(\mathrm{~s}, 1 \mathrm{H}), 7.87(\mathrm{~s}, 1 \mathrm{H}), 7.83(\mathrm{~d}, 1 \mathrm{H}, J=8.1 \mathrm{~Hz}), 7.50(\mathrm{~s}, 1 \mathrm{H}), 7.45(\mathrm{~m}, 5 \mathrm{H}), 7.35-7.21(\mathrm{~m}$, $11 \mathrm{H}), 6.10(\mathrm{~d}, 1 \mathrm{H}, J=15.3 \mathrm{~Hz}), 5.90(\mathrm{~m}, 1 \mathrm{H}), 5.32(\mathrm{~d}, 1 \mathrm{H}, J=17.1 \mathrm{~Hz}), 5.25(\mathrm{~d}, 1 \mathrm{H}, J=10.2 \mathrm{~Hz})$, $4.99(\mathrm{~d}, 1 \mathrm{H}, J=6.9 \mathrm{~Hz}), 4.56(\mathrm{dd}, 2 \mathrm{H}, J=5.7,2.7 \mathrm{~Hz}), 3.87$ (q, 1H, $J=6.6 \mathrm{~Hz}), 2.85(\mathrm{dd}, 1 \mathrm{H}$, $J=13.2,6.9 \mathrm{~Hz}), 2.62(\mathrm{dd}, 1 \mathrm{H}, J=13.2,5.7 \mathrm{~Hz}), 1.66(\mathrm{~s}, 9 \mathrm{H}) .{ }^{13} \mathrm{C} \mathrm{NMR}\left(75 \mathrm{MHz}, \mathrm{CDCl}_{3}\right) \delta_{\mathrm{C}} \mathrm{ppm}$ : $167.7,156.2,149.0,144.5,135.4,132.4,129.8,129.4,128.4,127.2,124.0,123.5,123.0,120.6,120.5$, $118.8,118.5,116.2,104.3,85.0,67.8,66.6,54.3,33.6,28.3$.

3.5.9. (R,Z)-tert-Butyl 3-(2-(2-amino-3-(tritylthio)propanamido)vinyl)-5,6-dibromo-1H-indole-1carboxylate $(Z-11)$

To a stirred solution of enamide (Z)-10 (1.53 g, $1.81 \mathrm{mmol})$ in $\mathrm{CH}_{2} \mathrm{Cl}_{2}$ (46 mL) was added successively $\mathrm{PhSiH}_{3}(4.46 \mathrm{~mL}, 36.2 \mathrm{mmol})$ and $\mathrm{Pd}\left(\mathrm{PPh}_{3}\right)_{4}(313 \mathrm{mg}, 0.27 \mathrm{mmol})$. After stirring for $30 \mathrm{~min}$ at $23{ }^{\circ} \mathrm{C}$ all volatiles were evaporated and the crude mixture was purified by flash chromatography on silica gel (hexane:EtOAc, 2:1) to afford pure (Z)-11 (1.17 g, 85\% yield) as a brown solid. ${ }^{1} \mathrm{H}$ NMR $\left(300 \mathrm{MHz}, \mathrm{CDCl}_{3}\right) \delta_{\mathrm{H}} \mathrm{ppm}: 9.57(\mathrm{~d}, 1 \mathrm{H}, J=12.0 \mathrm{~Hz}), 8.48(\mathrm{~s}, 1 \mathrm{H}), 7.77(\mathrm{~s}, 1 \mathrm{H}), 7.59$ $(\mathrm{s}, 1 \mathrm{H}), 7.43(\mathrm{~m}, 5 \mathrm{H}), 7.25(\mathrm{~m}, 10 \mathrm{H}), 6.92(\mathrm{dd}, 1 \mathrm{H}, J=11.0,8.7 \mathrm{~Hz}), 5.69(\mathrm{~d}, 1 \mathrm{H}, J=9.3 \mathrm{~Hz}), 3.12(\mathrm{~m}$, $1 \mathrm{H}), 2.77(\mathrm{dd}, 1 \mathrm{H}, J=9.0,4.5 \mathrm{~Hz}), 2.66(\mathrm{dd}, 1 \mathrm{H}, J=12.9,8.4 \mathrm{~Hz}), 1.66(\mathrm{~s}, 9 \mathrm{H}) .{ }^{13} \mathrm{C} \mathrm{NMR}(75 \mathrm{MHz}$, $\left.\mathrm{CDCl}_{3}\right) \delta_{\mathrm{C}}$ ppm: $170.5,148.8,144.4,129.5,128.0,127.9,126.9,123.9,123.8,122.6,122.5,120.6$, $120.2,118.5,114.8,99.2,84.7,67.1,53.7,36.8,28.1$.

3.5.10. (R,E)-tert-Butyl 3-(2-(2-amino-3-(tritylthio)propanamido)vinyl)-5,6-dibromo-1H-indole-1carboxylate $(E-\mathbf{1 1})$

To a stirred solution of enamide $(E)-\mathbf{1 0}(265 \mathrm{mg}, 0.31 \mathrm{mmol})$ in $\mathrm{CH}_{2} \mathrm{Cl}_{2}(8 \mathrm{~mL})$ was added successively $\mathrm{PhSiH}_{3}(0.77 \mathrm{~mL}, 6.3 \mathrm{mmol})$ and $\mathrm{Pd}\left(\mathrm{PPh}_{3}\right)_{4}(54 \mathrm{mg}, 0.05 \mathrm{mmol})$. After stirring for $25 \mathrm{~min}$ at $23{ }^{\circ} \mathrm{C}$ all volatiles were evaporated and the crude mixture was purified by flash chromatography on silica gel (hexane:EtOAc, 2:1) to obtain $(E)-11\left(170 \mathrm{mg}, 72 \%\right.$ yield) as a brown solid. ${ }^{1} \mathrm{H}$ NMR $\left(300 \mathrm{MHz}, \mathrm{CDCl}_{3}\right) \delta_{\mathrm{H}}$ ppm: $9.14(\mathrm{~d}, 1 \mathrm{H}, J=11.4 \mathrm{~Hz}), 8.48(\mathrm{~s}, 1 \mathrm{H}), 7.86(\mathrm{~s}, 1 \mathrm{H}), 7.45(\mathrm{~m}, 6 \mathrm{H})$, $7.37-7.20(\mathrm{~m}, 11 \mathrm{H}), 6.10(\mathrm{~d}, 1 \mathrm{H}, J=15.3 \mathrm{~Hz}), 3.14(\mathrm{~m}, 1 \mathrm{H}), 2.78(\mathrm{~m}, 1 \mathrm{H}), 2.67(\mathrm{~m}, 1 \mathrm{H}), 1.68(\mathrm{~s}, 9 \mathrm{H})$. ${ }^{13} \mathrm{C}$ NMR $\left(75 \mathrm{MHz}, \mathrm{CDCl}_{3}\right) \delta_{\mathrm{C}} \mathrm{ppm}: 170.6,149.0,144.7,135.4,132.3,129.8,129.5,128.2,127.1$, $124.0,123.2,120.5,120.4,118.7,116.5,103.6,84.9,67.4,53.9,37.2,28.3$.

3.5.11. tert-Butyl 5,6-dibromo-3-((6R,9R,Z)-2,2-dimethyl-4,7,10-trioxo-6,9-bis((tritylthio)methyl)-3oxa-5,8,11-triazatridec-12-en-13-yl)-1H-indole-1-carboxylate (Z-12)

To a stirred solution of amine (Z)-11 (3.75 g, $4.92 \mathrm{mmol})$ and $N$-boc-L-( $S$-trityl)-cys $(2.73 \mathrm{~g}, 5.91$ mmol) in anhydrous $\mathrm{CH}_{2} \mathrm{Cl}_{2}$ :DMF $(4: 1,59 \mathrm{~mL}: 15 \mathrm{~mL})$ at $0{ }^{\circ} \mathrm{C}$, were added diisopropylethylamine (DIPEA) (1.28 mL, $7.4 \mathrm{mmol})$, 1-hydroxybenzotriazole (HOBt) $(730 \mathrm{mg}, 5.41 \mathrm{mmol})$ and 
$N, N, N^{\prime}, N^{\prime}$-tetramethyl-O-(7-azabenzotriazol-1-yl)uronium hexafluorophosphate (HATU) (2.05 g, $5.41 \mathrm{mmol})$. After $30 \mathrm{~min}$ the cold bath was removed and the reaction mixture was stirred at $23{ }^{\circ} \mathrm{C}$ for $2 \mathrm{~h}$, quenched with a saturated aqueous solution of $\mathrm{NH}_{4} \mathrm{Cl}$, poured into $\mathrm{H}_{2} \mathrm{O}$ and extracted with $\mathrm{CH}_{2} \mathrm{Cl}_{2}$. The combined organic phases were dried over anhydrous $\mathrm{Na}_{2} \mathrm{SO}_{4}$, filtered and concentrated. The residue was purified by flash chromatography on silica gel (hexane:EtOAc, 4:1) to give pure (Z)-12 (4.97 g, 84\% yield) as a yellow solid. ${ }^{1} \mathrm{H}$ NMR (300 $\left.\mathrm{MHz}, \mathrm{CDCl}_{3}\right) \delta_{\mathrm{H}} \mathrm{ppm}: 8.44(\mathrm{~d}, 1 \mathrm{H}$, $J=11.3 \mathrm{~Hz}), 8.41(\mathrm{~s}, 1 \mathrm{H}), 7.72(\mathrm{~s}, 1 \mathrm{H}), 7.38(\mathrm{~m}, 10 \mathrm{H}), 7.30(\mathrm{~s}, 1 \mathrm{H}), 7.25(\mathrm{~m}, 20 \mathrm{H}), 6.89(\mathrm{dd}, 1 \mathrm{H}$, $J=11.4,9.0 \mathrm{~Hz}), 6.02$ (br s, 1H), $5.60(\mathrm{~d}, 1 \mathrm{H}, J=9.6 \mathrm{~Hz}), 5.09$ (br s, 1H), $4.16(\mathrm{~m}, 1 \mathrm{H}), 3.92(\mathrm{~m}, 1 \mathrm{H})$, $2.88(\mathrm{~m}, 1 \mathrm{H}), 2.55$ (dd, 1H, $J=12.9,4.5 \mathrm{~Hz}), 2.49$ (m, 1H), 2.37 (dd, 1H, $J=12.6,6.3 \mathrm{~Hz}), 1.69$ (s, 9H), 1.27 (s, 9H). ${ }^{13} \mathrm{C}$ NMR $\left(75 \mathrm{MHz}, \mathrm{CDCl}_{3}\right) \delta_{\mathrm{C}} \mathrm{ppm}: 171.3,167.7,155.4,149.3,144.5,144.3,134.6$, $131.0,129.7,129.6,128.3,128.2,127.2,127.1,126.6,125.2,123.6,122.9,120.4,118.5,114.1,100.3$, $85.1,80.6,67.6,67.1,53.5,52.4,34.1,32.1,28.4,28.3$.

3.5.12. tert-Butyl 5,6-dibromo-3-((6R,9R,E)-2,2-dimethyl-4,7,10-trioxo-6,9-bis((tritylthio)methyl)-3oxa-5,8,11-triazatridec-12-en-13-yl)-1H-indole-1-carboxylate $(E-12)$

To a stirred solution of amine $(E)-11(170 \mathrm{mg}, 0.22 \mathrm{mmol})$ and $N$-boc-L- $(S$-trityl)-cys $(124 \mathrm{mg}$, $0.27 \mathrm{mmol})$ in anhydrous $\mathrm{CH}_{2} \mathrm{Cl}_{2}$ :DMF $(4: 1,2.6 \mathrm{~mL}: 0.7 \mathrm{~mL})$ at $0{ }^{\circ} \mathrm{C}$, were added DIPEA $(58 \mu \mathrm{L}$, $0.33 \mathrm{mmol}$ ), HOBt (33 mg, $0.24 \mathrm{mmol})$ and HATU (93 mg, $0.24 \mathrm{mmol})$. After $20 \mathrm{~min}$ the cold bath was removed and the reaction mixture was stirred at $23{ }^{\circ} \mathrm{C}$ for $2.4 \mathrm{~h}$, quenched with a saturated aqueous solution of $\mathrm{NH}_{4} \mathrm{Cl}$, poured into $\mathrm{H}_{2} \mathrm{O}$ and extracted with $\mathrm{CH}_{2} \mathrm{Cl}_{2}$. The combined organic phases were dried over anhydrous $\mathrm{Na}_{2} \mathrm{SO}_{4}$, filtered and concentrated. The residue was purified by flash chromatography on silica gel (hexane:EtOAc, 3:1) to afford $(E)-\mathbf{1 2}$ (184 mg, 73\% yield) as a yellow solid. ${ }^{1} \mathrm{H}$ NMR $\left(300 \mathrm{MHz}, \mathrm{CDCl}_{3}\right) \delta_{\mathrm{H}} \mathrm{ppm}: 8.86(\mathrm{~d}, 1 \mathrm{H}, J=10.5 \mathrm{~Hz}), 8.49(\mathrm{~s}, 1 \mathrm{H}), 7.81(\mathrm{~s}, 1 \mathrm{H})$, $7.50-7.36(\mathrm{~m}, 11 \mathrm{H}), 7.34-7.16(\mathrm{~m}, 21 \mathrm{H}), 6.34(\mathrm{~d}, 1 \mathrm{H}, J=8.1 \mathrm{~Hz}), 6.25(\mathrm{~d}, 1 \mathrm{H}, J=14.4 \mathrm{~Hz}), 4.87$ (br s, 1H), $4.40(\mathrm{~m}, 1 \mathrm{H}), 3.65(\mathrm{~m}, 1 \mathrm{H}), 3.15(\mathrm{dd}, 1 \mathrm{H}, J=12.3,5.4 \mathrm{~Hz}), 2.70$ (dd, $1 \mathrm{H}, J=13.2,4.5 \mathrm{~Hz})$, $2.56(\mathrm{~m}, 1 \mathrm{H}), 2.38(\mathrm{dd}, 1 \mathrm{H}, J=12.9,4.5 \mathrm{~Hz}), 1.66(\mathrm{~s}, 9 \mathrm{H}), 1.26(\mathrm{~s}, 9 \mathrm{H})$.

3.5.13. tert-Butyl 5,6-dibromo-3-((Z)-2-((4R,7R)-7-((tert-butoxycarbonyl)amino)-6-oxo-1,2,

5-dithiazocane-4-carboxamido)vinyl)-1H-indole-1-carboxylate $(Z-13)$

Over a solution of $\mathrm{I}_{2}(897 \mathrm{mg} ; 3.54 \mathrm{mmol})$ in $\mathrm{CH}_{2} \mathrm{Cl}_{2}: \mathrm{CH}_{3} \mathrm{OH}(10: 1 ; 1416 \mathrm{~mL})$ a solution of $(Z)-12$ (610 mg; $0.50 \mathrm{mmol})$ in $\mathrm{CH}_{2} \mathrm{Cl}_{2}(100 \mathrm{~mL})$ was added at $23{ }^{\circ} \mathrm{C}$. The reaction mixture was stirred over $40 \mathrm{~min}$, and a $5 \%$ aqueous solution of $\mathrm{Na}_{2} \mathrm{~S}_{2} \mathrm{O}_{4}$ was added. The aqueous layer was extracted with $\mathrm{CH}_{2} \mathrm{Cl}_{2}$, the combined organic layers were dried over $\mathrm{Na}_{2} \mathrm{SO}_{4}$, filtered, and concentrated under vacuum. The residue obtained was purified by flash chromatography on silica gel (hexane:EtOAc, 3:1) to give pure (Z)-13 (302 mg, 83\% yield) as a white solid. ${ }^{1} \mathrm{H}$ NMR (300 $\left.\mathrm{MHz}, \mathrm{CDCl}_{3}\right) \delta_{\mathrm{H}}$ ppm: (mixture of conformers, signals for major conformer) $9.90(\mathrm{~d}, 1 \mathrm{H}, J=11.1 \mathrm{~Hz}), 8.45(\mathrm{~s}, 1 \mathrm{H}), 7.78$ $(\mathrm{s}, 1 \mathrm{H}), 7.62(\mathrm{~s}, 1 \mathrm{H}), 7.08(\mathrm{t}, 1 \mathrm{H}, J=9.9 \mathrm{~Hz}), 5.81(\mathrm{~d}, 1 \mathrm{H}, J=9.9 \mathrm{~Hz}), 5.65(\mathrm{br} \mathrm{s}, 1 \mathrm{H}), 5.05($ br s, $1 \mathrm{H})$, $4.93(\mathrm{~m}, 1 \mathrm{H}), 4.48(\mathrm{~m}, 1 \mathrm{H}), 3.67(\mathrm{~m}, 1 \mathrm{H}), 3.37-2.87(\mathrm{~m}, 3 \mathrm{H}), 1.70(\mathrm{~s}, 9 \mathrm{H}), 1.25(\mathrm{~s}, 9 \mathrm{H}) .{ }^{13} \mathrm{C} \mathrm{NMR}$ $\left(75 \mathrm{MHz}, \mathrm{CDCl}_{3}\right) \delta_{\mathrm{C}} \mathrm{ppm}$ : (signals for major conformer) 172.3, 167.3, 154.8, 149.1, 130.3, $125.4,125.1,124.1,123.7,122.3,120.7,118.9,114.0,101.9,85.2,80.6,57.1,54.5,43.2,41.8$, 28.6, 28.3. 
3.5.14. tert-Butyl 5,6-dibromo-3-((E)-2-((4R,7R)-7-((tert-butoxycarbonyl)amino)-6-oxo-1,2, 5-dithiazocane-4-carboxamido)vinyl)-1 $H$-indole-1-carboxylate $(E-13)$

Over a solution of $\mathrm{I}_{2}(265 \mathrm{mg} ; 1.04 \mathrm{mmol})$ in $\mathrm{CH}_{2} \mathrm{Cl}_{2}: \mathrm{CH}_{3} \mathrm{OH}(10: 1 ; 416 \mathrm{~mL})$ a solution of $(E)-12$ (180 mg; $0.15 \mathrm{mmol})$ in $\mathrm{CH}_{2} \mathrm{Cl}_{2}(30 \mathrm{~mL})$ was added at $23{ }^{\circ} \mathrm{C}$. The reaction mixture was stirred over $40 \mathrm{~min}$, and a $5 \%$ aqueous solution of $\mathrm{Na}_{2} \mathrm{~S}_{2} \mathrm{O}_{4}$ was added. The aqueous layer was extracted with $\mathrm{CH}_{2} \mathrm{Cl}_{2}$, the combined organic layers were dried over $\mathrm{Na}_{2} \mathrm{SO}_{4}$, filtered, and concentrated under vacuum. The residue obtained was purified by flash chromatography on silica gel (hexane:EtOAc, 6:4) to obtain pure $(E)-13$ (65 mg, 62\% yield) as a white solid. ${ }^{1} \mathrm{H} \mathrm{NMR}\left(300 \mathrm{MHz}, \mathrm{CDCl}_{3}\right) \delta_{\mathrm{H}}$ ppm: (mixture of conformers, signals for major conformer) $9.40(\mathrm{~d}, 1 \mathrm{H}, J=10.5 \mathrm{~Hz}), 8.32(\mathrm{~s}, 1 \mathrm{H}), 7.70(\mathrm{~s}, 1 \mathrm{H}), 7.44$ $(\mathrm{s}, 1 \mathrm{H}), 7.34(\mathrm{~m}, 1 \mathrm{H}), 6.92(\mathrm{~d}, 1 \mathrm{H}, J=11.1 \mathrm{~Hz}), 6.21(\mathrm{~d}, 1 \mathrm{H}, J=15.0 \mathrm{~Hz}), 5.10(\mathrm{br} \mathrm{s}, 1 \mathrm{H}), 5.01(\mathrm{~m}, 1 \mathrm{H})$, $4.80(\mathrm{~m}, 1 \mathrm{H}), 3.78(\mathrm{~m}, 1 \mathrm{H}), 3.45(\mathrm{~m}, 1 \mathrm{H}), 3.05(\mathrm{~m}, 1 \mathrm{H}), 2.87(\mathrm{~m}, 1 \mathrm{H}), 1.63(\mathrm{~s}, 9 \mathrm{H}), 1.42(\mathrm{~s}, 9 \mathrm{H}) .{ }^{13} \mathrm{C}$ NMR (75 MHz, $\left.\mathrm{CDCl}_{3}\right) \delta_{\mathrm{C}}$ ppm: (signals for major conformer) 173.3, 166.7, 155.6, 148.9, 135.1, 129.2, $123.7,122.8,120.4,120.2$, 118.5, 115.9, 115.7, 105.5, 85.0, 81.1, 53.8, 48.8, 42.8, 36.9, 28.6, 28.3.

\subsubsection{Tanjungide A (1)}

Over a solution of $(Z)-\mathbf{1 3}(310 \mathrm{mg} ; 0.43 \mathrm{mmol})$ in $\mathrm{CH}_{2} \mathrm{Cl}_{2}(9.3 \mathrm{~mL})$ was dropwise added TFA $(2.8 \mathrm{~mL})$ at $0{ }^{\circ} \mathrm{C}$. The reaction mixture was stirred at $0{ }^{\circ} \mathrm{C}$ for $8 \mathrm{~h}$ and a saturated aqueous solution of $\mathrm{NaHCO}_{3}$ was added until $\mathrm{pH}$ 8. The organic layer was extracted with EtOAc $(\times 3)$, the combined organic layers were dried over $\mathrm{Na}_{2} \mathrm{SO}_{4}$, filtered and concentrated under vacuum. The residue obtained was purified by flash chromatography on silica gel $\left(\mathrm{CH}_{2} \mathrm{Cl}_{2}: \mathrm{CH}_{3} \mathrm{OH}, 30: 1\right)$ to yield pure Tanjungide A (1) (135 mg, 60\% yield) as a pale yellow solid and exhibited physical and spectroscopic characteristics $\left({ }^{1} \mathrm{H},{ }^{13} \mathrm{C}\right.$ NMR and MS) equivalent to those reported in 3.3 .

\subsubsection{Tanjungide B (2)}

Over a solution of $(E)-\mathbf{1 3}(52 \mathrm{mg} ; 0.07 \mathrm{mmol})$ in $\mathrm{CH}_{2} \mathrm{Cl}_{2}(1.6 \mathrm{~mL})$ was dropwise added TFA $(0.47 \mathrm{~mL})$ at $0{ }^{\circ} \mathrm{C}$. The reaction mixture was stirred at $0{ }^{\circ} \mathrm{C}$ for $3 \mathrm{~h}$ and a saturated aqueous solution of $\mathrm{NaHCO}_{3}$ was added until $\mathrm{pH}$ 8. The organic layer was extracted with EtOAc $(\times 3)$, the combined organic layers were dried over $\mathrm{Na}_{2} \mathrm{SO}_{4}$, filtered and concentrated under vacuum. The residue obtained was purified by flash chromatography on silica gel $\left(\mathrm{CH}_{2} \mathrm{Cl}_{2}: \mathrm{CH}_{3} \mathrm{OH}, 20: 1\right)$ to give pure Tanjungide $\mathrm{B}$ (2) (16 mg, 45\% yield) as a pale yellow solid and exhibited physical and spectroscopic characteristics $\left({ }^{1} \mathrm{H},{ }^{13} \mathrm{C}\right.$ NMR and MS) equivalent to those reported in section 3.3.

\subsection{Biological Activity}

A549 (ATCC CCL-185), lung carcinoma; HT29 (ATCC HTB-38), colorectal carcinoma and MDA-MB-231 (ATCC HTB-26), breast adenocarcinoma cell lines were obtained from the ATCC. Cell lines were maintained in RPMI medium supplemented with $10 \%$ fetal calf serum (FCS), $2 \mathrm{mM}$ L-glutamine and $100 \mathrm{U} / \mathrm{mL}$ penicillin and streptomycin, at $37{ }^{\circ} \mathrm{C}$ and $5 \% \mathrm{CO}_{2}$. Triplicate cultures were incubated for $72 \mathrm{~h}$ in the presence or absence of test compounds (at ten concentrations ranging from 10 to $0.0026 \mu \mathrm{g} / \mathrm{mL}$ ). For quantitative estimation of cytotoxicity, the colorimetric sulforhodamine B (SRB) method was used [14]. Briefly, cells were washed twice with PBS, fixed for 15 min in $1 \%$ 
glutaraldehyde solution, rinsed twice in PBS, and stained in $0.4 \%$ SRB solution for 30 min at room temperature. Cells were then rinsed several times with $1 \%$ acetic acid solution and air-dried. Sulforhodamine B was then extracted in $10 \mathrm{mM}$ trizma base solution and the absorbance measured at $490 \mathrm{~nm}$. Results are expressed as $\mathrm{GI}_{50}$, the concentration that causes $50 \%$ inhibition in cell growth after correction for cell count at the start of the experiment (NCI algorithm). Doxorubicin and DMSO (solvent) were used as the positive and negative controls in this assay. Prism 3.03 from GraphPad was used for the statistical analysis of the cell growth inhibition results.

\section{Conclusions}

In summary, we have isolated, determined the structure and completed the first total synthesis of Tanjungides A and B, two new bromoindole enamides with interesting cytotoxic properties from the tunicate Diazona cf formosa. The total synthesis confirmed the structural assignment and provides rapid access to these new natural products and related analogues for biological evaluation and drug development.

\section{Acknowledgments}

The authors thank Susana González for recording the NMR experiments; Luis F. García-Fernández for performing the cytotoxicity assays; Santiago Bueno and Carlos de Eguilior for collection of the tunicate; Sebastiano Gulinello for logistical support with the diving expedition; Xavier Turon, Centre for Advanced Studies of Blanes (CEAB-CSIC), for the taxonomic identification of the sample; and Democratic Republic of Timor Leste, Ministry of Agriculture and Fisheries, Area of Agriculture, Fisheries and Livestock, Comoro-Dili for facilitating this work.

\section{Conflicts of Interest}

The authors declare that CM, LC, RF, MJM, AF, SM and CC are employees of PharmaMar. FR was an employee of PharmaMar.

\section{References}

1. Menna, M.; Fattorusso, E.; Imperatore, C. Alkaloids from marine ascidians. Molecules 2011, 16, 8694-8732.

2. Blunt, J.W.; Copp, B.R.; Keyzers, R.A.; Munro, M.H.G.; Prinsep, M.R. Marine natural products. Nat. Prod. Rep. 2013, 30, 237-323.

3. Vervoort, H.C.; Richards-Gross, S.E.; Fenical, W.; Lee, A.Y.; Clardy, J. Didemnimides A-D: Novel, predator-deterrent alkaloids from the caribbean mangrove ascidian Didemnum conchyliatum. J. Org. Chem. 1997, 62, 1486-1490.

4. Seldes, A.M.; Rodríguez, M.F.; Hernández, L.; Palermo, J.A. Identification of two meridianins from the crude extract of the tunicate Aplidium meridianum by tandem mass spectrometry. Nat. Prod. Res. 2007, 21, 555-563.

5. Bokesch, H.R.; Pannell, L.K.; McKee, T.C.; Boyd, M.R. Coscinamides A, B and C, three new bis indole alkaloids from the marine sponge Coscinoderma sp. Tetrahedron Lett. 2000, 41, 6305-6308. 
6. Sato, H.; Tsuda, M.; Watanabe, K.; Kobayashi, J. Rhopaladins A-D, new indole alkaloids from marine tunicate Rhopalaea sp. Tetrahedron 1998, 54, 8687-8690.

7. Appleton, D.R.; Copp, B.R. Kottamide E, the first example of a natural product bearing the amino acid 4-amino-1,2-dithiolane-4-carboxylic acid (Adt). Tetrahedron Lett. 2003, 44, 8963-8965.

8. Parsons, T.B.; Spencer, N.; Tsang, C.W.; Grainger, R.S. Total synthesis of kottamide E. Chem. Commun. 2013, 49, 2296-2298.

9. Reyes, F.; Fernández, R.; Rodríguez, A.; Francesch, A.; Taboada, S.; Ávila, C.; Cuevas, C. Aplicyanins A-F, new cytotoxic bromoindole derivatives from the marine tunicate Aplidium Cyaneum. Tetrahedron 2008, 64, 5119-5123.

10. Lindquist, N.; Fenical, W. Isolation and structure determination of Diazonamides A and B, unusual cytotoxic metabolites from the marine ascidian Diazona chinensis. J. Am. Chem. Soc. 1991, 11, 2303-2304.

11. Fernández, R.; Martín, M.J.; Rodríguez-Acebes, R.; Reyes, F.; Francesch, A.; Cuevas, C. Diazonamides $\mathrm{C}-\mathrm{E}$, new cytotoxic metabolites from the ascidian Diazona sp. Tetrahedon Lett. 2008, 49, 2283-2285.

12. Whitson, E.L.; Ratnayake, A.S.; Bugni, T.S.; Harper, M.K.; Ireland, C.M. Isolation, structure elucidation, and synthesis of Eudistomides A and B, lipopeptides from a fijian ascidian Eudistoma sp. J. Org. Chem. 2009, 74, 1156-1162.

13. Marfey, P. Determination of D-amino acids. II. Use of a bifunctional reagent, 1,5-difluoro-2, 4-dinitrobenzene. Carlsberg Res. Commun. 1984, 49, 591-596.

14. Skehan, P.; Storeng, R.; Scudiero, D.; Monks, A.; McMahon, J.; Vistica, D.; Warren, J.T.; Bokesch, H.; Kenney, S.; Boyd, M.R. New colorimetric cytotoxicity assay for anticancer-drug screening. J. Natl. Cancer Inst. 1990, 82, 1107-1112.

15. Boyd, E.M.; Sperry, J. Synthesis of the selective neuronal nitric oxide synthase (nNOS) inhibitor 5,6-dibromo-2'-demethylaplysinopsin. Synlett 2011, 6, 826-830.

16. Seyferth, S.; Heeren, J.K.; Singh, G.; Grim, S.O.; Hughes, W.B. Studies in phosphinemethylene chemistry: XIII. Routes to triphenylphosphine-halomethylenes and -dihalomethylenes. J. Organomet. Chem. 1966, 5, 267-274.

17. Stork, G.; Zhao, K. A stereoselective synthesis of (Z)-1-iodo-1-alkenes. Tetrahedron Lett. 1989, $30,2173-2174$.

18. Jiang, L.; Job, G.E.; Klapars, A.; Buchwald, S.L. Copper-catalyzed coupling of amides and carbamates with vinyl halides. Org. Lett. 2003, 5, 3667-3669.

19. Kamber, B.; Hartmann, A.; Eisler, K.; Riniker, B.; Rink, H.; Sieber, P.; Rittel, W. The synthesis of cystine peptides by iodine oxidation of $S$-trityl-cysteine and $S$-acetamidomethyl-cysteine peptides. Helv. Chim. Acta 1980, 63, 899-915.

20. Boger, D.L.; Ichikawa, S.; Tse, W.C.; Hedrick, M.P.; Jin, F.Q. Total synthesis of thiocoraline and BE-22179 and assessment of their DNA binding and biological properties. J. Am. Chem. Soc. 2001, 123, 561-568.

(C) 2014 by the authors; licensee MDPI, Basel, Switzerland. This article is an open access article distributed under the terms and conditions of the Creative Commons Attribution license (http://creativecommons.org/licenses/by/3.0/). 